\title{
Biodiversity of Fusarium species in Mexico associated with ear rot in maize, and their identification using a phylogenetic approach
}

\author{
Irma Morales-Rodríguez ${ }^{1}$, María de J. Yañez-Morales ${ }^{2}$, Hilda V. Silva-Rojas ${ }^{1}$, \\ Gabino García-de-los-Santos ${ }^{1} \&$ Doralinda A. Guzmán-de-Peña ${ }^{3}$ \\ ${ }^{1}$ Colegio de Postgraduados (CP), Campus Montecillo, Seed Production Program, Montecillo, Edo. de \\ Mexico, CP 56230, Mexico; ${ }^{2}$ CP-Institute of Phytopathology, Montecillo, CP 56230, Edo. De Mexico, \\ Mexico; ${ }^{3}$ Department of Biotechnology and Biochemistry, CINVESTAV-Unidad Irapuato, $\mathrm{km} 9.6$ Carr, \\ Irapuato-León, Guanajuato, CP 36500, Mexico
}

Received 19 January 2006; accepted in revised form 6 November 2006

\begin{abstract}
Fusarium proliferatum, F. subglutinans, and F. verticillioides are known causes of ear and kernel rot in maize worldwide. In Mexico, only F. verticillioides and F. subglutinans, have been reported previously as causal agents of this disease. However, Fusarium isolates with different morphological characteristics to the species that are known to cause this disease were obtained in the Highland-Valley region of this country from symptomatic and symptomless ears of native and commercial maize genotypes. Moreover, while the morphological studies were not sufficient to identify the correct taxonomic position at the species level, analyses based in the Internal Transcribed Spacer region and the Nuclear Large Subunit Ribosomal partial sequences allowed for the identification of $F$. subglutinans, $F$. solani, and $F$. verticillioides, as well as four species ( $F$. chlamydosporum, $F$. napiforme, $F$. poae, and $F$. pseudonygamai) that had not previously been reported to be associated with ear rot. In addition, $F$. napiforme and $F$. solani were absent from symptomless kernels. Phylogenetic analysis showed genetic changes in F. napiforme, and F. pseudonygamai isolates because they were not true clones, and probably constitute separate sibling species. The results of this study suggest that the biodiversity of Fusarium species involved in ear rot in Mexico is greater than that reported previously in other places in the world. This new knowledge will permit a better understanding of the relationship between all the species involved in ear rot disease and their relationship with maize.
\end{abstract}

Key words: fungus, ITS, nLSU, seed, Zea mays

\section{Introduction}

Maize (Zea mays L.) is one of the four basic food staples of the world population [1] and at the same time is the crop that has the first place in production volume in the world. In developed countries most of the maize produced is used for animal feed and industrial uses other than human food [2]. In Mexico maize is the main human food source and per capita consumption is estimated to be $328 \mathrm{~g} \mathrm{day}^{-1}$ [3].

The majority of the reported maize diseases, affecting roots, stalks, ears, and kernels, are caused by fungi [4]. Among these diseases, ear rot is one of the most important in all the countries where this cereal is grown. In addition to reduced crop yield, ear rot adverasely affects the physical, physiological, and phytosanitary qualities of the seed $[5,6]$. The causal agents reported worldwide as responsible for ear rot are Fusarium proliferatum, $F$. subglutinans, and F. verticillioides [4]. These pathogens survive in the soil, in infected plant debris, and inside apparently healthy seed and can affect the embryo and pericarp without visible symptoms. Infection can be seedborne and systemic in the crop from seedling to harvest, or starting during the pollination where the silks are 
infected by the airborne conidia. During harvest, ear rot appears as individual rotted kernels or as randomly scattered groups of rotted kernels $[4,7]$. In addition, depending on the specific fungus responsible for the ear rot, the production of mycotoxins can be an important source of contamination.

The three Fusarium species involved in ear rot disease are included in the Gibberella fujikuroi complex [7, 8]. Morphological differences between the three species are an important step in the classification, however, currently there is no consensus definition among research groups that will allow definitive identification based on morphology alone. Revisions in recent years have asserted that the first criteria to define a Fusarium species [7], was the use of the biological species concept, but it has some limitations. Some researchers have adopted the concept of phylogenetic species which considers the use of one or more conserved genes or sequences to define a species of this genus [9], such as the Internal Transcribed Spacer (ITS) region of the ribosomal genes 18S-5.8S-28S [10].

In Mexico, the species that have been found to cause ear rot are $F$. verticillioides [11] and $F$. subglutinans $[12,13]$, and since this disease is the most important in the Highland Valley, based on reduced yield and grain quality [8], the aim of this research was to determine the biodiversity of the Fusarium species associated with ear rot in this geographical area of the country utilizing both a morphological and phylogenetic approach.

\section{Materials and methods}

During the fall-winter of 2002, at the Colegio de Postgraduados' plots, located in MontecilloHighland-Valley (elevation $2250 \mathrm{~m}$ ), in the central part of Mexico, 10 symptomatic and two symptomless ears from each one of 28 native maize genotypes were collected (Table 1).

\section{Symptomatic and symptomless ear isolates}

The ears of all the genotypes with visible rot symptoms were grouped according to the mycelium colour. Of each group, a fungal sample grown on the top of the kernels was taken to obtain monoconidial cultures. To isolate the fungi that were within the symptomless kernels, hundred of
Table 1. Relation of 28 native maize genotypes and their origin in the Highland of Mexico ${ }^{\mathrm{a}}$

\begin{tabular}{|c|c|}
\hline Genotypes & Origin \\
\hline ASV11 & Sierra Purepecha, Michoacan \\
\hline ASV34 & Sierra Purepecha, Michoacan \\
\hline ASV36 & Sierra Purepecha, Michoacan \\
\hline ASV45 & Sierra Purepecha, Michoacan \\
\hline ASV49 & Sierra Purepecha, Michoacan \\
\hline ASV64 & Sierra Purepecha, Michoacan \\
\hline ASV71 & Sierra Purepecha, Michoacan \\
\hline ASV76 & Sierra Purepecha, Michoacan \\
\hline ASV84 & Sierra Purepecha, Michoacan \\
\hline ASV86 & Sierra Purepecha, Michoacan \\
\hline ASV87 & Sierra Purepecha, Michoacan \\
\hline ASV102 & Sierra Purepecha, Michoacan \\
\hline ASV111 & Sierra Purepecha, Michoacan \\
\hline ASV112 & Sierra Purepecha, Michoacan \\
\hline $\begin{array}{l}\text { Qro-21 } \\
\text { (Chalqueño Qro) }\end{array}$ & Sierra Purepecha, Michoacan \\
\hline $\begin{array}{l}\text { Zac-66 } \\
\text { (Chalqueño Dgo-Zac) }\end{array}$ & Sierra Purepecha, Michoacan \\
\hline $\begin{array}{l}\text { Hgo- } 88 \\
\text { (Chalqueño Hgo) }\end{array}$ & Sierra Purepecha, Michoacan \\
\hline $\begin{array}{l}\text { Pedro Cruz } \\
\text { (7a CSM) } \\
\text { (Chalco Crema) }\end{array}$ & Sierra Purepecha, Michoacan \\
\hline $\begin{array}{l}\text { Santos Altamirano } \\
\text { 6a CSM } \\
\text { (Chalco palomo) }\end{array}$ & $\begin{array}{l}\text { Valle de Chalco, Edo. de } \\
\text { Mexico }\end{array}$ \\
\hline $\begin{array}{l}\text { Comp. Familias } \\
\text { (Chalqueño Cajetes) }\end{array}$ & $\begin{array}{l}\text { Valle de Chalco, Edo. de } \\
\text { Mexico }\end{array}$ \\
\hline $\begin{array}{l}\text { Manuel Montes de Oca } \\
\text { (Ciclo 8) }\end{array}$ & $\begin{array}{l}\text { Valle de Chalco, Edo. de } \\
\text { Mexico }\end{array}$ \\
\hline $\begin{array}{l}\text { David Rivera Enrrique } \\
\text { (1a CSM) }\end{array}$ & $\begin{array}{l}\text { Valle de Chalco, Edo. de } \\
\text { Mexico }\end{array}$ \\
\hline $\begin{array}{l}\text { Pedro Cruz Linares } \\
\text { (8a CSM) }\end{array}$ & $\begin{array}{l}\text { Valle de Chalco, Edo. de } \\
\text { Mexico }\end{array}$ \\
\hline $\begin{array}{l}\text { Ignácio Rosas } \\
\text { (7a CSM) }\end{array}$ & $\begin{array}{l}\text { Valle de Chalco, Edo. de } \\
\text { Mexico }\end{array}$ \\
\hline $\begin{array}{l}\text { David Rivera Reyes } \\
\text { (2a CSM) }\end{array}$ & $\begin{array}{l}\text { Valle de Chalco, Edo. de } \\
\text { Mexico }\end{array}$ \\
\hline $\begin{array}{l}\text { Pedro Hernandez } \\
\text { (Ciclo 8) }\end{array}$ & $\begin{array}{l}\text { Valle de Chalco, Edo. de } \\
\text { Mexico }\end{array}$ \\
\hline $\begin{array}{l}\text { Santos Altamirano } \\
\text { (7a CSM) }\end{array}$ & $\begin{array}{l}\text { Valle de Chalco, Edo. de } \\
\text { Mexico }\end{array}$ \\
\hline Oaxaca 492 & Oaxaca \\
\hline
\end{tabular}

${ }^{\text {a }}$ The native maize genotypes are grown from 1900 to $2700 \mathrm{~m}$ elevation.

seeds were randomly chosen from the apparently healthy ears and mixed. The seeds were disinfested using a 3:1 solution of sodium hypochlorite $1.5 \%$, and ethanol $25 \%$ for $2 \mathrm{~min}$. After that, they were rinsed three times with sterile distilled water. Internal fungi were obtained through the Blotter method [14]. The colonies that developed over the seed were examined microscopically. Fusarium 
colonies were selected according to the mycelium colour.

\section{Monoconidial cultures}

The mycelium of each group selected from symptomatic and symptomless kernels was placed into $10 \mathrm{ml}$ test tubes with $5 \mathrm{ml}$ of sterile distilled water, and shaken in a Mini Vortex (VWR, USA). The content of individual tubes was poured into Petri dishes with water-agar (WA) (18 g of agar/l) and allowed to stay on the plates for $10 \mathrm{~s}$ and then the excess was removed. The Petri dishes were maintained at room temperature $\left(22-24^{\circ} \mathrm{C}\right)$ for $24 \mathrm{~h}$. The germinated conidia were transferred to new Petri dishes containing Potato Carrot Agar medium (PCA) (20 g of potato, $20 \mathrm{~g}$ of carrot, and $15 \mathrm{~g}$ of agar/l) and kept at room temperature with constant white light for seven days. The conidia were transferred into sterile glycerol $25 \%$, and stored in Eppendorf tubes at $-84^{\circ} \mathrm{C}$.

\section{Morphological characterization}

To identify the fungi at the genus level, the Manual of Barnett and Hunter [15] was used and the determination of the species was according to Booth [16], Nelson et al. [17], and Burgess et al. [18]. Also the descriptions of Marasas et al. [19], Pascoe [20], and Nirenberg and O'Donnell [21] were referred to when necessary.

\section{Colour of the colony}

The Fusarium cultures were placed into slant tubes containing Potato Dextrose Agar medium (PDA) ( $250 \mathrm{~g}$ of potato, $20 \mathrm{~g}$ of dextrose, and $20 \mathrm{~g}$ of agar/l) amended with a half-cup of potato pulp. To promote sporulation and colouring, the tubes were maintained at $20^{\circ} \mathrm{C}$ with continuous white light for 10 days [17]. Finally, the colour of the mycelia was evaluated on both sides, the tubes were grouped according to the colour, and only one isolate was selected from each group for further morphological and phylogenetic analysis.

\section{Structure formation}

To set up microcultures in humidity chambers, Petri dishes were used [22]. Aluminium foil, a microscope slide, and a PDA square of $5 \mathrm{~mm}^{3}$ were placed in the plate, in this order one over the other, and a portion of mycelia was taken and placed on each PDA square. A cover slide was placed over the inoculated PDA squares. The Petri dishes were sealed and maintained at $\pm 24^{\circ} \mathrm{C}$ under white (12 h) and black light (12 h) (365 nmGeneral Electric $40 \mathrm{~W}$ F40SL, Mexico) for seven days. After the mycelia colonized the cover slide it was removed with sterile forceps and permanently mounted on a microscope slide with a drop of acidified glycerol. The size, shape and other key characteristics of each structure were recorded and photomicrographs were taken with a digital camera (Nikon COOLPIX 5000, Japan).

\section{Obtaining of macroconidia and napiforme microconidia}

The isolates were placed on Carnation-Leaf-Agar medium (CLA) (18 $\mathrm{g}$ of agar/1), and 10 carnation leaves were amended to the medium before the agar solidified [23], the leaves were irradiated previously with gamma rays at the Nuclear Centre of Mexico. The Petri dishes were kept at room temperature $\left(22-24^{\circ} \mathrm{C}\right)$ with white light for 25 days, and then permanently mounted for microscopic evaluation.

\section{Formation of microconidia into chains}

To stimulate this structure isolates were grown in $\mathrm{KCl}$ medium ( $8 \mathrm{~g}$ of $\mathrm{KCl}$, and $14 \mathrm{~g}$ of agar/l) amended with 10 carnation leaves. The Petri dishes were kept at room temperature $\left(22-24^{\circ} \mathrm{C}\right)$ under black light for 10 days, and the aerial mycelium was microscopically examined.

\section{Formation of chlamydospores}

This conserved structure was induced in PDA medium, and the Petri dishes were kept at room temperature $\left(22-24^{\circ} \mathrm{C}\right)$ with white light for 14 days.

\section{Phylogenetic analysis}

The DNA of 21 monosporic cultures was obtained with the protocol of Ahrens and Seemüller [24], and quality was verified by electrophoresis on a $1 \%$ agarose gel (Ultrapure, Gibco, USA) using TBE buffer (Tris-Borate-EDTA pH 8.0). The 
gel was stained with ethidium bromide and the amplicons were visualized in a transilluminator (Gel Doc 2000, BIO RAD ${ }^{\circledR}$, USA). The DNA concentration was quantified in a Perkin-Elmer spectrophotometer (Lambda BIO 10, USA).

To amplify the ITS region ITS5 (5'-GGAAGTAAAAGTCGTAACAAGG-3') and ITS4 (5'TCCTCCGCTTATTGATATGC-3') [10], primers were used, and to amplify a partial sequence of $28 \mathrm{~S}$ rRNA gene, ITS5 and NL4 (5'-GGTCCGTGTTTCAAGACGG-3') primers were used [10, 11]. PCR master mix was prepared in a final volume of $25 \mu 1$ containing $1 \times$ of Taq DNA buffer, $0.13 \mathrm{mM}$ of $\mathrm{MgCl}_{2}, 16 \mu \mathrm{M}$ of dNTPs, 20 pmole of each primer, $0.4 \mathrm{U}$ of Taq-DNA polymerase (University Biotecnologies ${ }^{\circledR}$, Mexico), and $80 \mathrm{ng}$ of DNA. PCR was carried out in a Perkin-Elmer thermocycler (CT 2400 ICA, USA) with an initial denaturing at $95^{\circ} \mathrm{C}$ for $2 \mathrm{~min}$; 30 cycles of denaturing at $95^{\circ} \mathrm{C}$ for $1 \mathrm{~min}$, annealing at $50^{\circ} \mathrm{C}$ for $30 \mathrm{~s}$, and extension at $72^{\circ} \mathrm{C}$ for $2 \mathrm{~min}$; afterwards at $72^{\circ} \mathrm{C}$ for $10 \mathrm{~min}$ as single final extension cycle. The PCR product was purified using a QIAquick kit (Qiagen, USA) according to the instructions given by the manufacturer. The fragment amplified was verified on a $0.8 \%$ agarose gel, and the gel was stained as above. The remaining PCR-products were sequenced in both directions in an ABI PRISM 3700 (Applied Biosystems, USA). The sequences were edited with Lasergene 2001, V.5 Software (DNASTAR Inc., USA), and the most related sequence was obtained using GenBankBlast (NCBI-National Centre for Biotechnology Information). DNA sequences were aligned with the profile mode of Clustal W, and an evolutionary distances matrix was generated with Kimura 2 parameter substitution model. The evolutionary tree for the datasets was constructed with the neighbour-joining algorithm and the confidence of the tree was assessed by bootstrap analysis based on 5000 boot strap replications using MEGA 3.1 software [25].

\section{Results and discussion}

\section{Isolates obtained}

Of the symptomatic and symptomless kernels, eight and 13 isolates were obtained, respectively, on the basis of colour in PDA slant tubes (Table 2).

\section{Morphological characterization}

Typical Fusarium structures were observed in the 21 isolates selected. In general, we observed noncoloured septate mycelium, globular to fusiform microconidia with zero to three septate; falcate to cylindric macroconidia with seven septate according to the species; and the mesoconidia (the third type of Fusarium conidia) with zero to three septate [21], some species had brown coloured chlamydospores (Figure 1).

The species identified morphologically were F. chlamydosporum $(9.52 \%)$, F . napiforme $(14.29 \%)$, F. poae (14.29\%), F.pseudonygamai $(23.8 \%)$, F. solani $(14.29 \%), F$. subglutinans $(14.29 \%)$, and $F$. verticillioides $(9.52 \%)$ (Table 2$)$.

Four species of Fusarium; F. napiforme (37.5\%), F. solani $(37.5 \%)$, F. subglutinans $(12.5 \%)$, and $F$. verticillioides $(12.5 \%)$, were obtained from symptomatic kernels, however from apparently healthy kernels five species were isolated out of which only two were present in both symptomatic and symptomless kernels; $F$. subglutinans (15.4\%) and F. verticillioides $(7.7 \%)$. The remaining Fusarium colonies belonged to three different species; $F$. chlamydosporum $(15.4 \%), F$. poae $(23 \%)$, and $F$. pseudonygamai $(38.5 \%)$. These results indicate that these species of Fusarium are latent inside the seed as reported by White and Munkvold and Desjardins [4, 5], and when the phytopathogenic species have appropriate environmental conditions they grow systemically and affect the crop, thus, becoming sources of dissemination of these pathogens to other areas.

The seven species found are associated with other maize diseases, and were found throughout the plants. $F$. proliferatum, $F$. subgutinans, and $F$ verticillioides have been isolated in leaf axil and other maize tissues during ear fill, while $F$. solani was only reported associated with maize in India [26, 27]. F. poae, and $F$. solani, which cause head blight and root rot in maize, are transmitted by seed [16, 28]. F. chlamydosporum, F. poae, and $F$. pseudonygamai have been associated with other gramineous species such as Pennisetum typhoides and Sorghum caffrorum [19].

Five of the species identified produce mycotoxins such as fusaric acid and/or fumonisin (F. napiforme, F. subglutinans, and F. verticillioides); fusarin $(F$. poae, and $F$. verticillioides), moniliformin 


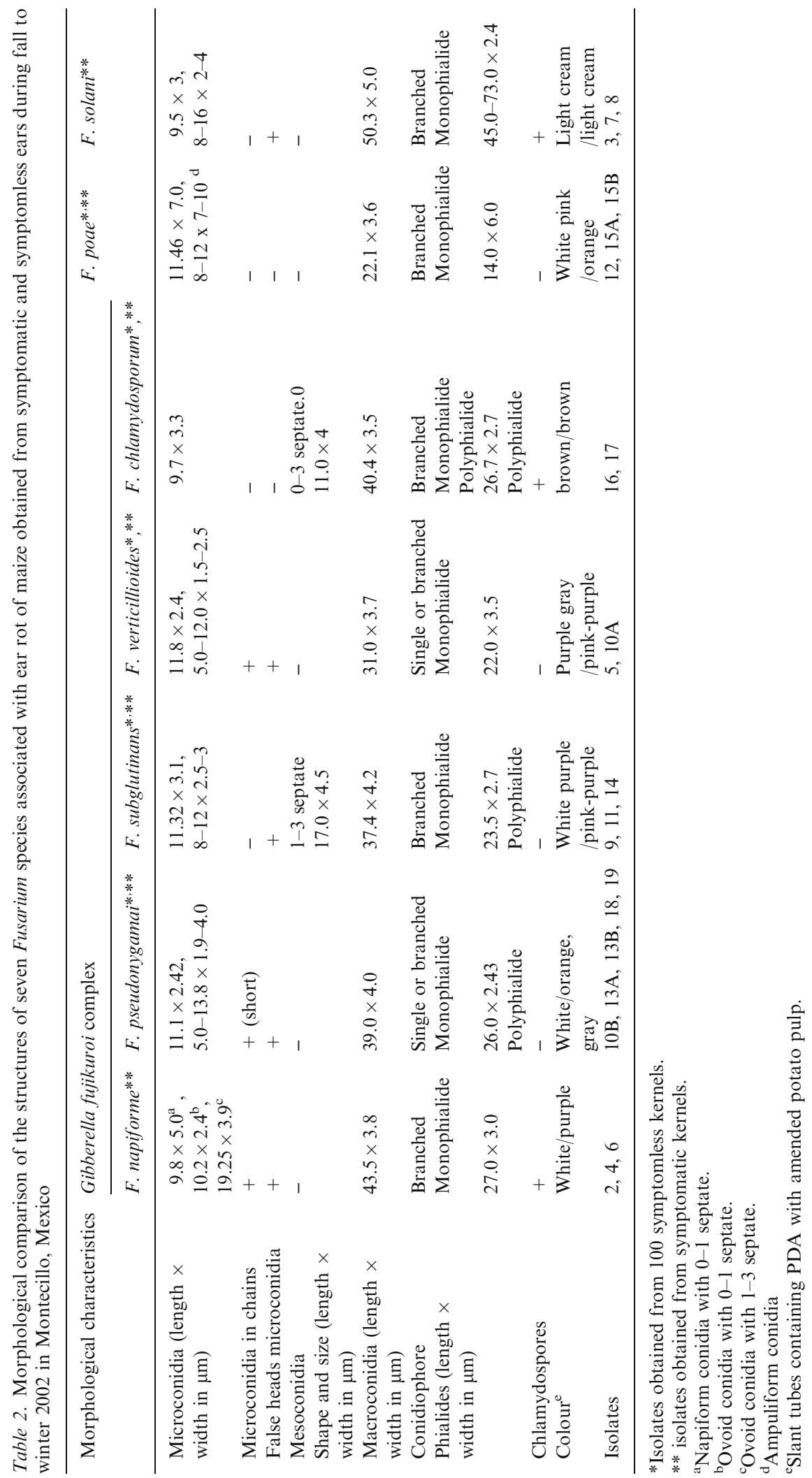



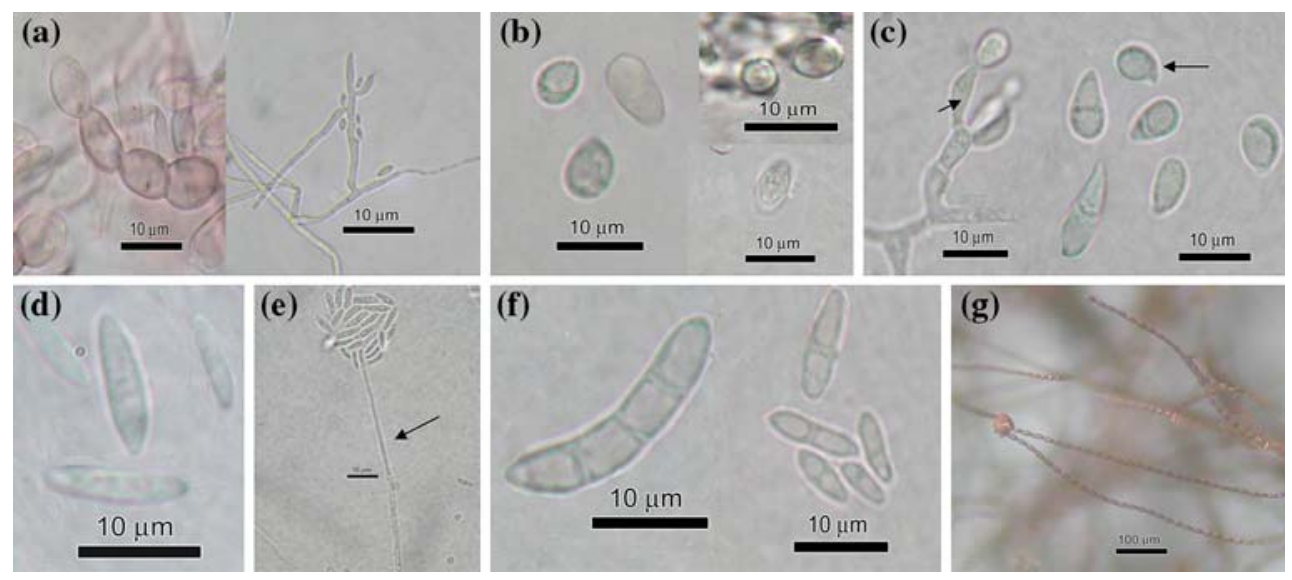

Figure 1. Morphological differential features of Fusarium species. (a) F. chlamydosporum: brown chlamydospores in chains and polyphialide, (b) $F$. napiforme: napiform microconidia (globose with a small protuberance), (c) $F$. poae: ampuliform microconidia with papilla, $0-1$ septate and monophialide, (d). F.

(F. chlamydosporum, F. napiforme, F. subglutinans, and $F$. verticillioides); trichothecenes ( $F$. poae) and naphthazarin ( $F$. verticillioides) in maize kernels [29]. $F$. pseudonygamai, and $F$. solani have not been reported to produce mycotoxins [21, 29, 30].

\section{Phylogenetic analysis}

\section{Analysis of ITS and $n L S U$ regions}

PCR was successfully performed and bands ((550 bp) were obtained. Each sequence was compared to sequences of the same species deposited at GenBank. Similarities ranged from $99.6 \%$ to $100 \%$. Total nucleotides amplified were $470-533 \mathrm{bp}$ and corresponded to the ITS1 and ITS2 complete regions; the $3^{\prime}$ portion of the $18 \mathrm{~S}$ gene, $5.8 \mathrm{~S}$ complete sequence, and the $5^{\prime}$ end of the $28 \mathrm{~S}$ gene. PCRproducts corresponding to nLSU gene were approximately $600 \mathrm{bp}$. With respect to ITS sequences, the isolate identified morphologically as $F$. chlamydosporum did not have any ITS sequence corresponding to the species deposited at GenBank database, so its closest relative was Fusarium spp. (AF158314) with a percentage of similarity of 98.6\% (Table 3).

The 28S rRNA gene partial sequences showed the same results as the ITS region. However, in the case of the isolate identified morphologically as F. chlamydosporum it was $98.6 \%$ equal to F. chlamydosporum (accession number AY213706). This result could be explained considering that for pseudonygamai: large microconidia aseptate, (e) F. solani: false heads microconidia, and large monophialide, (f) F. subglutinans: large mesoconidia, fusiform, straight $1-3$ septate, and G. F. verticillioides: microconidia in large chains observed on Petri dish under the low power of the microscope $10 \times$.

some species of Gibberella fujikuroi complex, the $28 \mathrm{~S}$ gene gives a better resolution than ITS region. The ITS and nLSU sequences were deposited at Genbank NCBI (Table 3). Also, all isolates were placed in the Fungal Collection of Colegio de Postgraduados (registration on World Data Centre for Microorganisms in process).

The species formed two clusters (Cluster I and II) (Figure 2). Cluster I had two groups (Group 1 and 2). Group 1 corresponded to two of the 16 sections as proposed by Wollenweber and Reinking [17] and both sections were in the G. fujikuroi complex [21]; Liseola section with $F$. pseudonygamai, F. subglutinans, and F. verticillioides, and Dlaminia section with $F$. napiforme. Group 2 also had two subgroups as evidenced by nucleotidic differences in the sequences of the isolates (Figure 3). F. pseudonygamai (DQ297559) had a cytosine at base 99 of ITS1, and not a thiamine as the other isolates of this species and $F$. napiforme (DQ297555) had a thiamine at base 99 of ITS1, and not a cytosine as in the isolate DQ297553. The isolate DQ 297554 of this species had a guanine at base 29 , which corresponded to the beginning of the $28 \mathrm{~S}$ gene. It also did

Figure 2. Phylogenetic tree based on ITS region of 21 Mexican isolates of Fusarium species obtained from ear rot (symptomatic and symptomless kernels) using Kimura 2 parameter substitution method. The evolutionary scheme was constructed with the neighbor-joining algorithm using MEGA 3.1 software. The confidence of the tree was assessed by bootstrap analysis based on 5000 replications. 
Table 3. Molecular characterization of 21 Fusarium isolates from symptomatic and symptomless ear rot of maize using ITS region in Mexico

\begin{tabular}{|c|c|c|c|c|c|c|}
\hline Isolates & $\begin{array}{l}\text { Morphological } \\
\text { identification }\end{array}$ & $\begin{array}{l}\text { Accession most } \\
\text { related (Blast-GenBank) }\end{array}$ & $\begin{array}{l}\text { Value } \\
\text { of } \mathrm{A}^{\mathrm{a}}\end{array}$ & $\begin{array}{l}\text { Similarity } \\
\text { index }^{\mathrm{b}}\end{array}$ & $\begin{array}{l}\text { Difference in } \\
\text { nucleotides }\end{array}$ & Proceeding \\
\hline 16 & F. chlamydosporum DQ297572 & Fusarium sp. AY213706 & 1001 & 100 & 0 & USA \\
\hline 17 & F. chlamydosporum DQ297573 & Fusarium sp. AY213706 & 1001 & 100 & 0 & USA \\
\hline 2 & F. napiforme DQ297553 & F. napiforme X94175 & 1005 & 99.8 & 1 & Netherlands \\
\hline 4 & F. napiforme DQ297554 & F. napiforme X94175 & 1021 & 99.6 & 2 & Netherlands \\
\hline 6 & F. napiforme DQ297555 & F. napiforme X94175 & 1021 & 100 & 0 & Netherlands \\
\hline 12 & F. poae DQ297556 & F. poae AY053440 & 963 & 100 & 0 & Norway \\
\hline $15 \mathrm{~A}$ & F. poae DQ297557 & F. poae AY053440 & 942 & 99.8 & 0 & Norway \\
\hline $15 B$ & F. poae DQ297558 & F. poae AY053440 & 942 & 100 & 0 & Norway \\
\hline $10 \mathrm{~B}$ & F. pseudonygamai DQ297559 & F. pseudonygamai U34563 & 985 & 99.8 & 1 & USA \\
\hline $13 \mathrm{~A}$ & F. pseudonygamai DQ297560 & F. pseudonygamai U34563 & 1005 & 100 & 0 & USA \\
\hline $13 \mathrm{~B}$ & F.pseudonygamai DQ297561 & F. pseudonygamai U34563 & 1005 & 100 & 0 & USA \\
\hline 18 & F. pseudonygamai DQ297562 & F. pseudonygamai U34563 & 985 & 100 & 0 & USA \\
\hline 19 & F. pseudonygamai DQ297563 & F. pseudonygamai U34563 & 985 & 100 & 0 & USA \\
\hline 3 & F. solani DQ297564 & F. solani AY755617 & 977 & 99.6 & 2 & Mexico \\
\hline 7 & F. solani DQ297565 & F. solani AY755617 & 989 & 99.6 & 2 & Mexico \\
\hline 8 & F. solani DQ297566 & F. solani AY755617 & 1019 & 99.6 & 2 & Mexico \\
\hline 9 & F. subglutinans DQ297567 & F. subglutinans X94167 & 993 & 99.8 & 1 & Netherlands \\
\hline 11 & F. subglutinans DQ297568 & F. subglutinans X94167 & 999 & 99.8 & 1 & Netherlands \\
\hline 14 & F. subglutinans DQ297569 & F. subglutinans X94167 & 1019 & 99.8 & 1 & Netherlands \\
\hline 5 & F. verticillioides DQ297570 & F. verticillioides AY533376 & 1043 & 99.8 & 1 & Austria \\
\hline $10 \mathrm{~A}$ & F. verticillioides DQ297571 & F. verticillioides AY533376 & 999 & 99.8 & 1 & Austria \\
\hline
\end{tabular}

a Alignment.

bAlignment done with Lasergene 2001 V.5 software (DNASTAR, Inc. Madison, USA).

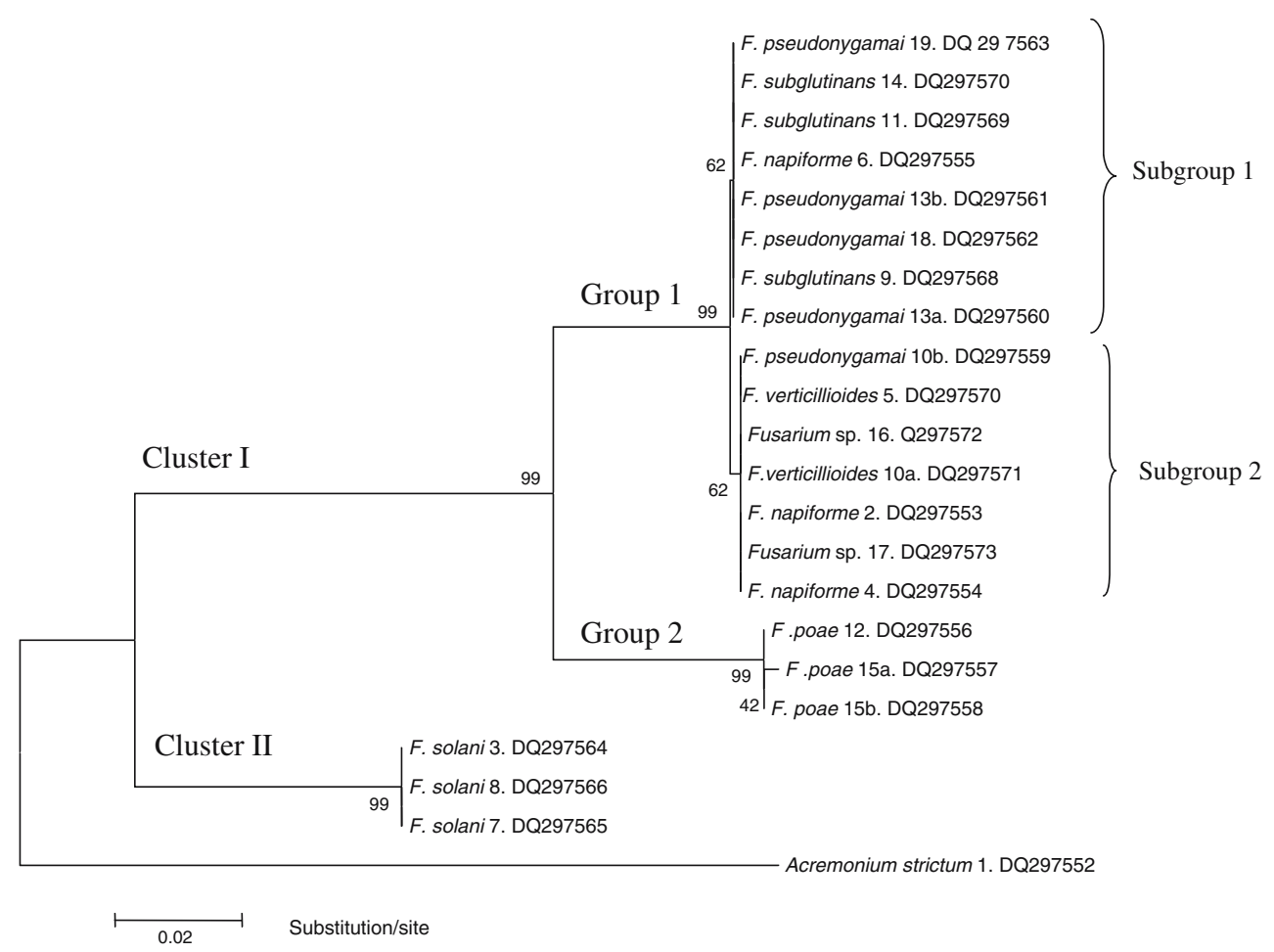



(a)
Fusarium pseudonygamai DQ297559 Fusarium pseudonygamai DQ297560 Fusarium pseudonygamai DQ297561 Fusarium pseudonygamai DQ297562 Fusarium pseudonygamai DQ297563
(b)
Fusarium napiforme Fusarium napiforme Fusarium napiforme

(c)

$\begin{array}{ll}\text { Fusarium napiforme } & \text { DQ297553 } \\ \text { Fusarium napiforme } & \text { DQ297554 } \\ \text { Fusarium napiforme } & \text { DQ297555 }\end{array}$

DQ297553 DQ297554 DQ2 97555 $\ldots{ }^{\star} \ldots \ldots$

CCCCAAACTC TGTTTCTATA TGTAACTTCT GAGTAAAACC ATAAATAAAT

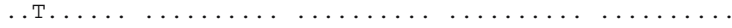

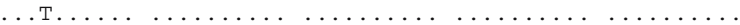

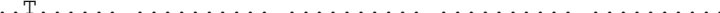

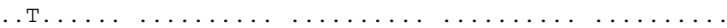

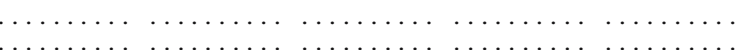

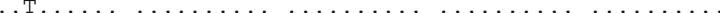

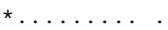

AGGAATACCC GCTGAACTTA A

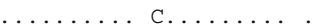

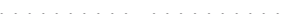

Figure 3. Alignment showing differences in nucleotides: (A) ITS1 of Fusarium pseudonygamai, base 99 (asterisk). (B) ITS1 of F. napiforme, base 99 (asterisk). (C) 28S gene of F. napiforme, base 29 (asterisk).

not have a cytosine as in the other two isolates analysed in this same region (Figure 3). These results clearly show that these two species, as well as F. subglutinans, are separated into reproductively isolated populations that probably constitute separate sibling species [7], and in the future they may form different monophyletic species.

Group 2 included three isolates of $F$. poae, of the Sporotrichiella section. Isolate DQ297557 had a thiamine at the 438 base of ITS2, and not an adenine as in the other two isolates.

In the cluster II there were the three $F$. solani isolates that have been grouped by Snyder and Hansen [18] in the Martiella y Ventricosum section of the F. solani complex [31]. Acremonium strictum was considered as and outgroup (Figure 3).

The position of species in the Liseola and Dlaminia sections in the same group can be explained by the fact that both had Gibberella as the teleomorph, are part of the same complex, and produce moniliformin. The isolates identified as $F$. chlamydosporum, according to its morphology and considered as Fusarium spp. by ITS Blast search, included in the same group was unexpected because its teleomorph is unknown. However, it produces moniliformin [29], and this fact might reflect its relation with the other species.

Through morphological and phylogenetic analysis, seven species of Fusarium identified as $F$. chlamydosporum, F. napiforme, F. poae, F. pseudonygamai, $F$. solani, $F$. subglutinans, and $F$. verticillioides, were found to be associated with ear rot disease, and $F$. chlamydosporum, $F$. poae, $F$. pseudonygamai, F. subglutinans, and $F$. verticillioides were found within asymptomatic kernels as well. Four of the identified species have not been reported previously to be associated with ear rot in Mexico. For this reason the biodiversity of Fusarium species involved in ear rot in Mexico appears to be greater than that reported previously in other places in the world. This new knowledge will permit a better understanding of the relationship between all the species involved in ear rot disease and their relationship with maize.

\section{Acknowledgements}

The first author wishes to express her thanks to Universidad Autonoma del Estado de Hidalgo, as well as to PROMEP-Program, for support of doctoral studies at the Colegio de Postgraduados in Mexico. All authors are grateful to CONACYT for financial support of this research through Grant 38409-V. We also thank Dr. Leobigildo Córdova-Téllez for his help in the field experiment, and MC Lily Zelaya-Molina for her comments during the writing of this paper.

\section{References}

1. Anderson PK, Cunningham AA, Patel NG, Morales FJ, Epstein PR, Daszak P. Emerging infectious diseases of plants: pathogen pollution, climate change and agrotechnology drivers. Trends Ecol. Evol. 2004; 19:535-544.

2. Farnham DE, Benson GO, Pearce RB.. Corn perspective, culture. In: White JP, Jonson AL, eds. Corn Chemistry and Technology, 2nd ed., American Association of Cereal Chemists Inc., St. Paul, MN, 2003: 1-34.

3. Figueroa $\mathbf{J}$ de D. La tortilla vitaminada. Avance $\mathrm{y}$ perspectiva 1999; 18: 149-158. 
4. White GD. Compendium of corn diseases, 3rd edn. St. Paul MN: APS Press, 2000: 78 pp.

5. Munkvold GP, Desjardins AE. Fumonisins in maize, can we reduce their ocurrence? Plant. Dis. 1997; 81:556-565.

6. Vigier B, Reid LM, Seifert KA, Stewart DW, Halminton RI.. Distribution and prediction of Fusarium species associated with maize ear rot in Ontario. Can. J. Plant Pathol. 1997; 19:60-65.

7. Steenkamp ET, Wingfield BD, Desjardins AE, Marasas WFO, Wingfield MJ. Cryptic speciation in Fusarium subglutinans. Mycologia 2002; 94:1032-1043.

8. Félix R, Romero S. Etiología de la germinación prematura del maíz en Huamantla, Tlaxcala. Agrociencia 1981; 43: 81-87.

9. O’Donnell K. Ribosomal DNA internal transcribed spacer are highly divergent in the phytopathogenic ascomycete Fusarium sambucinum (Gibberella pulicaries). Curr. Genet. 1992; 22:213-220.

10. White TJ, Bruns T, Lee S, Taylor J. Amplification and direct sequencing of fungal ribosomal RNA genes for phylogenetics. In: Innis MA, Gelfand DH, Sninsky JJ, White TJ, eds. PCR Protocols: A Guide to Methods and Applications, Academic Press, San Diego, CA, 1990: 315322.

11. Perez-Brito D, Jeffers D, Gonzales-de-Leon D, Khairallah M, Cortes-Cruz M, Velasquez-Cardelas G, Aspiroz-Rivero S, Srinivasam G. QTL mapping of Fusarium moniliforme ear rot resistance in highland maize, Mexico. Agrociencia 2001; 35:181-196.

12. Desjardins AE, Plattner RD, Gordon TR. Gibberella fujikuroi mating population A and Fusarium subglutinans from teosinte species and maize from Mexico and Central America. Mycol. Res. 2000; 104:865-872.

13. Steenkamp ET, Coutinho TA, Desjardins AE, Wingfield BD, Marasas WFO, Wingfield MJ. Gibberella fujikuroi mating population $\mathrm{E}$ is associated with maize and teosinte. Mol. Plant Pathol. 2001; 2:215-221.

14. Agarwal VK, Sinclair JB. Principles of Seed Pathology, Vol I. Boca Raton, Florida, USA: CRC Press, Inc., 1987.

15. Barnett HL, Hunter BB. Illustrated Genera of Imperfect Fungi. 4th edn. St. Paul MN: APS Press, 1998: 218 pp.

16. Booth C. The Genus Fusarium. Commonwealth Mycological Institute. CAB International. Kew, Surrey, England, 1971; $237 \mathrm{pp}$.

17. Nelson PE, Toussoun TA, Marasas WFO. Fusarium Species. An illustrated manual for identification. The Pensylvania State University. University Park and London. USA, 1983: 193 pp.

18. Burgess LW, Summerell BA, Bullock S, Gott KP, Backhouse D. Laboratory Manual for Fusarium Research, 3rd edn. Department of Crop Science. University of Sydney, Sydney. 1994: 133 pp.

19. Marasas WFO, Rabie CJ, Lübben A, Nelson PE, Toussoun TA. Fusarium napiforme, a new species from millet and sorghum in southern Africa. Mycologia 1987; 76:910-914.
20. Pascoe IG. Fusarium morphology I: identification and characterization of a tirad conidia type, the mesoconidium. Mycotaxon 1990; 37:150-160.

21. Nirenberg HL, O'Donnell K. New Fusarium species and combination within the Gibberella fujikuroi species complex. Mycologia 1998; 90:434-458.

22. Onnions AHS. Preservation of fungi. In: Booth C, ed. Methods in Microbiology, Academic Press, New York, 1971: 113-151.

23. Fisher NL, Marasas WFO, Toussoun TA. Taxonomic importance of microconidial chains in Fusarium section Liseola and effects of water potential in their formation. Mycologia 1983; 75:693-698.

24. Ahrens U, Seemüller E. Detection of DNA of plant pathogenic mycoplasma like organisms by polymerase chain reaction that amplifies a sequence of the $16 \mathrm{~S}$ rRNA gene. Phytopathology 1992; 82:828-832.

25. Kumar S, Tamura K, Nei M. MEGA3: Integrated software for Molecular Evolutionary Genetics Analysis and sequence alignment. Brief Bioinform. 2004; 5:150 163.

26. Dowd PF, Barnett CJ, Jonson ET, Beck JJ. Leaf axil sampling of midwest U.S. maize for mycotoxigenic Fusarium fungi using PCR analysis. Mycopathologia 2004; 158:431-440.

27. Varshney JL. Pathogenic fungi recorded in maize crop raised from exotic germplasm. Indian Phytopathol. 1988; 41:242-244.

28. Ocamb CM, Kommedahl T. Rhizosphere competence of Fusarium species colonizing corn roots. Phytopathology 1994; 84:166-172.

29. Desjardins AE, Proctor RH. Biochemistry and genetics of Fusarium toxins. In: Summerell BA, Leslie JF, Backhouse D, Bryden WL, Burguess LW, eds. Fusarium Paul E. Nelson Memorial Symposium, APS Press, St. Paul MN, 2001: 29-49.

30. Wayne LB, Logrieco A, Abbas HK, Porter JK, Vesonder RF, Richard JL, Cole RJ. Other significant Fusarium mycotoxins. In: Summerell BA, Leslie JF, Backhouse D, Bryden WL, Burguess LW, eds. Fusarium. Paul E. Nelson Memorial Symposium. St. Paul MN: APS Press, 2001: 360-392.

31. Matuo T, Snyder WC. Use of morphology and mating populations in the identification of formae speciales in Fusarium solani. Phytopathology 1973; 63:562-565.

Address for correspondence: I. Morales-Rodríguez, Colegio de Postgraduados, Campus Montecillo, Seed Production Program, km 36.5 Carr. Mexico-Texcoco, Montecillo, Edo. de Mexico CP 56230, Mexico

Phone: + 52-55-58045963; Fax: + 52-55-58045962

E-mail: imorales@colpos.mx 